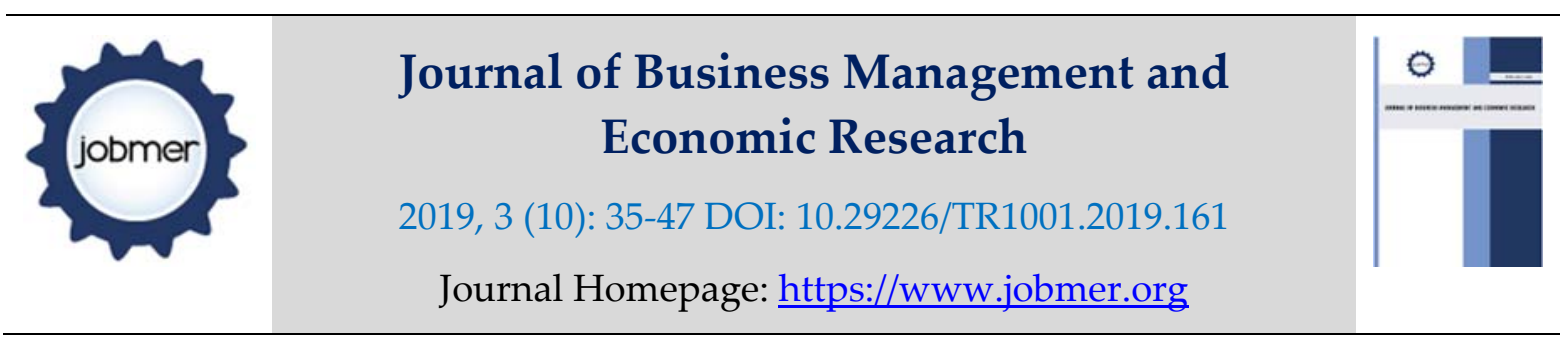

\title{
The Impact of Corruption on Economic Growth: A Case Study of South Asian Countries
}

\author{
Mallika Appuhamilage Kumudini Sriyalatha \\ University of Sri Jayewardenepura, Colombo, Sri Lanka \\ kumuduni@sjp.ac.lk
}

\begin{abstract}
Corruption threatens the integrity of markets, weakens fair competition, misleads resource allocation, damage public trust; undermine the rule of law and also its impact on the development of the economy as a whole. However, this is no common agreement regarding the impact of corruption on economic growth. A few scholars have identified that corruption and economic growth have positive relationship ((Leff, 1964; Huntington, 1968). Many studies have found that there is a negative relationship between these two variables (Mauro, 1995; Bardhan, 1997). The main objective of this study is to revisit the impact of corruption on economic growth. Using international, macro-level panel data from four South Asian countries with four independent variables, the study estimates the direct and indirect impact of corruption on economic growth for the period of 2002-2016. This study used the Phillips and Hansen (1990) Fully Modified Ordinary Least Square (FM-OLS) technique. The study employed the Levin, Lin \& Chu panel unit root test to identify the time series properties for the variables. According to the test results, the data series was integrated of order (1) and the study applied the FM-OLS procedure by using a panel data of four South Asian countries spanning over 2002-2016. The results suggested that corruption has both direct and indirect influence on economic growth in four countries; India, Pakistan, Bangladesh and Sri Lanka. First, the findings claimed that a one-unit increase in corruption retards economic growth by roughly 0.0282 percent for the period under consideration. Second, the econometric results revealed the positive effect of physical and human capital on economic growth. Third, results claimed that the effect of corruption on economic growth is sensitive to the inclusion of the transmission channels including physical capital and human capital. According to the findings, it is evident that actions should be taking to curb corruption at every level among the sample countries. Laws to decrease corruption should be vigorously pursued and imposed. Institutions should be established to enforce corruption laws and proper implementation of the existing laws is vital for reduce corruption among these countries. In doing so political commitment and support is an essential. Also, introducing the subject of professional ethics in field of education may form an important solution to combat the corruption.
\end{abstract}

Key words: Corruption, economic growth, human capital, physical capital, Transparency index

This article is an edited version of a paper presented at the $45^{\text {th }}$ International Scientific Conference on Economic and Social Development - XIX International Social Congress (ISC 2019) Moscow (Russia) 17-18 October, 2019. The author would like to thank the organizers and participants for their helpful comments. Financial support from the Faculty of Management Studies \& Commerce (FMSC), University of Sri Jayewardenepura, Sri Lanka is also gratefully acknowledged. 


\section{Introduction}

Recently the corruption is one of the biggest issues around the world. The corruption is closely linked with the governments' behavior and their activities and also with some of the government affairs in the economy. It is a hazard facing society and exits both in the developing and also the developed economies but more witness in the developing nations. Therefore, it is an indicator of a poorly functioning nation. The World Bank defines the corruption as 'the abuse of public power for private benefit". It does not mean that corruption is limited to only the public sector. It can be seen especially in large private enterprises also. Tanzi (1998) showed the corruption also occurs with private sector activities which are regulated by the government. Further, it highlighted that in many countries some proceeds of corruption go to funding the events of the political parties. Therefore, corruption has attracted a great deal of attention among researchers and international financial institutions during the last few decades, indicating its implications for economic growth. Johnston (1997) said that there was a high tendency to bring rapid political and economic change due to corruption but its consequence varies from one nation to another: It collapses some economies while gaining beneficial effect to some others. Further, researchers indicated that corruption was an increasingly important political and trade issue among countries and in international organizations.

Three are two thoughts of schools on corruption and economic growth relation. First thought of economics believed that corruption brings benefits to the economic development. Leff (1964) argued that politicians like to eliminate corruption since it can erode the power of the leading political party, mainly in a country with ethnic minorities or foreign business persons. Meanwhile, the repot highlighted that corrupt administrators can force the government to become involved in promoting economic activities and corruption provides safeguards against serious policy errors. Acemoglu and Verdier (1998) suggested that corruption enhanced efficiency in the economy and have a positive effect on economic growth.

The view of second school of thought shows that corruption has harmful effects on economic growth. Several authors have acknowledged in the literature that corruption reduce the productivity of the government expenditure, distorts the allocation of resources and therefore, reduce the economic growth. Monte and Papagni (2001) examined the long-run effect of corruption on the productivity of expenditure on public investment using a dynamic panel data approach. The result showed that the effect was significant and distinct from a direct negative effect of corruption on the growth rate. According to the World Bank's estimate in 2017, businesses and individuals paid $\$ 1.5$ trillion in bribes each year. This was about 2 percent of global GDP - and 10 times the value of overseas development assistance. Mo (2001) examined the role of corruption in economic growth. Findings of the study 
showed that a 1 percent increase in the corruption level reduces the growth rate by about 0.72 percent. The important finding of the study was that major source of corruption was from political instability which accounted about 53 percent of the total effect. Further, it revealed that corruption reduces the level of human capital and the share of private investment. Mauro (1995) investigated the relationship between corruption and economic growth by considering, the amount of red tape, the efficiency of the judicial system, and various categories of political stability for a cross section of countries. The study found that corruption reduces investment, thereby lowering economic growth. Corruption is on the rise in South Asia and failure to tackle it will threaten the region's economic progress, as well as efforts to share that progress equitably. The average score of South Asian countries Corruption Perception Index (CPI) in the 2013 was about 30 - lower than any other sub-region in the world. 80 percent of people in the region now feel that their government's actions in the fight against corruption are ineffective (Transparency International, 2014). Majority of the findings are consistent with the view that corruption is deleterious economic growth. As for South Asian countries particular, there has been little research in this field and thus the motivation of this study is the lack of evidence on this issue in this region.

The main objective of this study is to examine the impact of corruption on economic growth, in four South Asian Counties. Using international, macro-level data from four South Asian countries, the study estimates the multiple impact of corruption on economic growth for the period of 2002-2016.

The following section presents the earlier published theoretical foundation of the corruption and economic growth. Section 3 introduces the data and model of the empirical estimations. Section 4, discusses the empirical results of the study. The last section covers concluding remarks.

\section{Literature review}

There is a growing trend of research in recent years on the relationship between corruption and economic growth. The general conclusion is that corruption slows down the long-term economic growth of an economy through different channels. Mauro (1998) examined the relationship between corruption and government expenditure on education. The results revealed that there was a negative significant relationship between the variables. Mauro (1995) found strong empirical evidence to support the negative relationship between corruption and long-term growth. Mauro (1995) showed a 1 percent increase in the corruption level reduces the growth rate by about 0.72 percent after controlling for the level of per capita real GDP. Meanwhile this study found that political instability channel is the most important channel through which corruption affects economic performance. 
Ratbek (2014) examined how the quality of governance, the size of public spending, and economic development affect the relationship between bureaucratic corruption and economic growth. The result indicated that the interaction between corruption and governance shapes the efficiency of public spending. As a result of the efficiency of public spending this determines the growth effects of corruption. At the same time, the study revealed that corruption improves economic efficiency if the actual government size is above the optimal level. Further, it found that the occurrence of corruption declines with economic development. The argument behind this view is that because of economic advancements wage rate increases and it leads to higher seeking cost of private rent, thereby, discouraging corruption.

Enrlich and Lui (1999) examined the relationship between corruption, government and growth. In this study, the researchers have employed endogenous growth model. The result showed that a "balanced growth" is derived as a balancing act between accumulating human capital, which stimulates the economic growth. It revealed that the relationship between corruption and the economy is explained as endogenous outcome of competition between growth-enhancing and socially unproductive investments. In addition, findings of the study showed that the relationship between government, corruption, and the economy's growth is nonlinear.

Blackburn and Downing (2015) indicated that the way of influencing decentralisation to reduce the level of corruption and, thereby foster economic development. The analysis was done by employing a dynamic general equilibrium model. This study was emphasis that corruption affects growth through entry regulation and the costs of doing business. The study revealed that the decentralised structure of the government is associated with lower bribes, higher capital and higher economic growth

Monte and Papagni (2001) examined sources of corruption arises from purchases made by government officials. This study used dynamic panel data approach to economic growth based on time series for the period 1963-1991 for 20 Italian regions. Basically the study focused on the determinants of the rate of growth, corruption, public infrastructures and public expenditures. The results indicated that negative effects of corruption on economic growth from private investment and public investments.

Pellegrini and Gerlagh (2004) studied empirically connection between corruption and economic growth directly and indirectly through several indicators like trade policy, human capital, investment, and political instability. The findings of the research confirmed a negative effect of corruption economic growth. The outcomes further suggested that the most influential policy variables of corruption as investment and trade openness. 
Gyimah-Brempong (2002), examined the effects of corruption on the growth rate of per capita income and the distribution of income for 21 Africa countries from 1993 - 1999. The results showed that corruption decreases economic growth directly and indirectly through decreased investment in physical capital. According to empirical results, a one unit increase in corruption decreases growth rates of GDP by 0.75 and 0.9 percentage points and per capita income reduces between 0.39 and 0.41 percentage points per year in Africa. Further, it showed that corruption decreases growth directly through decreased productivity of resources and indirectly through reduced investment.

Méon and Sekkat (2005) investigated the relationship between the corruption and growth investment and the quality of governance in a sample of 63 to 71 countries for the period 1970 and 1998 . The findings of the study showed that negative effect of corruption on growth and investment. Moreover, they explained that a weak rule of law, an inefficient government and political violence lead to negative impact of corruption on investment.

Méndez and Sepúlveda (2006) studied the effects of corruption on long-run growth incorporating measures of political freedom as a key determinant of the relationship. They found the evidence of a non-monotonic relationship between corruption and growth after controlling for several economic variables for free countries. Moreover, the results showed that the growth-maximizing level of corruption was significantly greater than zero.

Aidt et al. (2008) examined the role of political accountability as a determinant of corruption and economic growth. They defined two governance regimes as low quality and high quality institutions and observe that corruption has no impact on growth in countries with low quality institutions. Meanwhile the results indicated that corruption has an adverse impact on economic growth in countries with high quality institutions only.

Kholdy and Sohrabian (2008) examined whether foreign direct investment can stimulate financial development in countries with the leaders who engage in corruption. They found that foreign direct investment may jump-start financial development in developing countries. Moreover, most of the causal links were found in developing countries which experience a higher level of corruption in the form of excessive patronage, nepotism, job reservation, 'favor-for-favors, and secret party funding. Furthermore, the results revealed that there is a suspiciously close relation between politics and business. Swaleheen and Stansel (2007) investigated the relationship between corruption and economic growth by incorporating the impact of economic freedom. The results showed that in countries with low economic freedom, corruption appears to reduce economic growth while in countries with high economic freedom, corruption is found to increase economic growth. 
Ehrlich (1996) examined the relationship between corruption, government, and growth. In contrast to the traditional perspective, the results showed that wealth and crime are positively related while corruption and per capita income levels are negatively related across a wide range of economic development.

Leff (1964) and Huntington (1968) revealed that the economic growth increases due to corruption in various ways including helping entrepreneurs to avoid bureaucratic delay by bribing officials. Lui (1996) also showed that increase corruption leads to increase progress of the economy by minimizing waiting costs thus reducing inefficiency in economic activity.

It is clear that there is no common conclusion about relationship between corruption and economic growth from the previous studies. There are claims on both sides of the impacts regarding corruption and economic growth. Studies, which claim that corruption has a negative effect on economic growth, tend to emphasis on the consequences of corruption for efficiency. The researchers who support this argument show that corruption influenced the growth of an economy through various channels; such as reductions in the quality of production of goods, investment in both physical and human capital. Corruption not only increases the cost of production but also reduces the quality of resources. On the other hand the studies which show the positive side of the corruption on economic growth advocate that corruption greases the wheels of business and trade and thus, contributes economic growth and investment.

\section{Data and Models}

This study used panel data in selected countries of South Asian Association for Regional Cooperation (SAARC) namely, India, Pakistan, Bangladesh and Sri Lanka. The country selection was done on the basis of availability of data on Corruption measures. Annual data spans from 2002-2016 and have extracted from World Development Indicators (World Bank) and World Economic Outlook (WEO) and Transparency International. The data used in this study consist of annual observations on corruption index (COR), economic growth (EG), physical capital (K) (proxied by investment as percentage of GDP), human capital (POP); the population growth is the proxy for human capital because the data on population is more reliable, and initial output (PC) (proxied by GDP per capita lagged by one period) for selected SAARC countries. The corruption index ranges from 0 to 100, with 100 indicating a highly clean country and 0 indicating a highly corrupt country.

The study employed the Phillips and Hansen (1990) Fully Modified Ordinary Least Square (FM-OLS) technique to find the long run estimates for the variables. The FM-OLS is particularly suitable for the 
study because it enables us to simultaneously correct for the effect of serial correlation in the error term and the endogeneity of the independent variables.

The FM-OLS test for a panel case was based on estimating the following equations:

$$
\begin{aligned}
& E G_{t}=\beta_{0}+\beta_{1} P O P+\beta_{2} C O R+\beta_{3} K+\beta_{4} P C+\varepsilon_{t} \\
& E G_{t}=\beta_{0}+\beta_{1} P O P+\beta_{2} C O R+\beta_{4} P C+\varepsilon_{t} \\
& E G_{t}=\beta_{0}+\beta_{2} C O R+\beta_{3} K+\beta_{4} P C+\varepsilon_{t} \\
& E G_{t}=\beta_{0}+\beta_{2} C O R+\beta_{4} P C+\varepsilon_{t} \\
& K_{t}=\beta_{0}+\beta_{1} P O P+\beta_{2} C O R+\beta_{5} E G+\varepsilon_{t} \\
& P O P_{t}=\beta_{0}+\beta_{2} C O R+\beta_{3} K+\beta_{5} E G+\varepsilon_{t}
\end{aligned}
$$

In equation (1), population growth (POP) and capital (K) was expected to have positively influence on economic growth (EG) (i.e. $\beta_{1}>0$ and $\beta_{3}>0$ ). However, corruption could either have positive or negative effect on the economic growth (i.e. $\beta_{2}><0$ ). On the other hand, corruption could have an impact on economic growth either directly or indirectly or both. Corruption reduces economic growth directly by promoting misallocation of resources and discouraging productive utilization of resources. And also indirectly, there is an impact on economic growth by reducing investment in the country. Based on these views, we developed equation (1) to account for the direct effect of corruption on economic growth meanwhile, the indirect effect of corruption on economic growth through equations (5) and (6), respectively. We used equation (5) to estimate the effect of corruption on investment. In equation (5), population growth (PG) was expected to have negative effect on capital (K) $\left(\beta_{1}<0\right)$. We developed equations (2) and (3) to assess the impact of transmission channels including physical capital and human capital, respectively on economic growth. The equation (4) shows the effect of corruption on economic growth without transmission channels.

\section{Empirical results}

Table 1 shows the descriptive statistics for economic growth (EG), human capital (POP),corruption index (COR), physical capital (K) and initial output (proxy by lagged value of GPD per capita) (PC) for the period of 2002 to 2016 . As can be seen from Table 1, the mean values of EG, POP, COR, K, and PC are 5.93 percent, 1.42 percent $29,26.84$ percent and US\$1264, respectively. The maximum and minimum values indicate cross-country variability among the variables used in the study. 
The average corruption index for the sample countries is approximately 29 , which is at the high end of the corruption scale. Economic growth on the other hand, averaged about 6 percent among the sample countries for the period of 2002 - 2016.

Table 1. Descriptive Statistics

\begin{tabular}{|c|c|c|c|c|c|}
\hline & EG & POP & COR & K & PC \\
\hline Mean & 5.932461 & 1.419643 & 29.03571 & 26.83929 & 1263.969 \\
\hline Median & 6.013693 & 1.400000 & 28.50000 & 27.20000 & 1028.739 \\
\hline Maximum & 10.25996 & 2.300000 & 40.00000 & 39.10000 & 3842.164 \\
\hline Minimum & 1.606692 & -2.100000 & 13.00000 & 14.12000 & 400.6136 \\
\hline Std. Dev. & 1.964454 & 0.630561 & 6.483445 & 7.281203 & 864.1379 \\
\hline
\end{tabular}

Source: Author Compiled

Table 2. Pearson Correlation Matrix

\begin{tabular}{|c|c|c|c|c|c|}
\hline & EG & POP & COR & K & PC \\
\hline EG & 1 & & & & \\
\hline POP & 0.00687 & 1.00000 & & & \\
\hline COR & 0.52715 & -0.49784 & 1.00000 & & \\
\hline K & 0.57429 & -0.62570 & 0.54941 & 1.00000 & \\
\hline PC & -0.01538 & -0.54772 & 0.65101 & 0.30896 & 1.00000 \\
\hline
\end{tabular}

Source: Author Compiled

Table 2 presents the Pearson's correlation coefficients corruption index, economic growth, physical capital, human capital, and GDP per capita. The results indicate that human capital, corruption and physical capital are positively correlated with economic growth. In contrast, GDP per capita and economic growth is negatively correlated.

Table 3. Levin, Lin \& Chu Panel Unit Root Test Results

\begin{tabular}{|c|c|c|}
\hline & \multicolumn{2}{|c|}{ First Difference } \\
\hline Variable & Statistics & Probability \\
\hline Economic Growth (EG) & -2.91821 & 0.0018 \\
\hline Human Capital (POP) & -5.28036 & 0.0000 \\
\hline Corruption (COR) & -3.16701 & 0.0008 \\
\hline
\end{tabular}




\begin{tabular}{|c|c|c|}
\hline Physical Capital (K) & -3.16158 & 0.0008 \\
\hline GDP Per Capita (PC) & -3.15093 & 0.0008 \\
\hline
\end{tabular}

Source : Author Compiled

Table 3 presents Levin, Lin \& Chu (LLC) panel unit root test results or the time series data from 2002 2016. Results suggest that the null of non-stationary cannot be rejected at levels for all the individual series, but at first difference, the null is rejected at 1 percent level of significance, thus suggesting that all the variables are first difference stationary. In all, the results from the LLC panel unit root suggest that the series have same order of integration [I (1)]. Hence, we estimate long-run relationships by using a FM-OLS model.

Table 4. Fully Modified OLS Results - Long-Run (Dependent Variable- Economic Growth)

\begin{tabular}{|l|c|r|r|r|}
\hline \multirow{2}{*}{$\begin{array}{l}\text { Independent } \\
\text { Variables }\end{array}$} & \multicolumn{4}{|c|}{ Equation } \\
\cline { 2 - 5 } Human Capital & $0.061349^{*}$ & \multicolumn{1}{|c|}{2} & \multicolumn{1}{c|}{3} \\
(POP) & $(1.810574)$ & 0.041444 & - & \multicolumn{1}{c|}{} \\
\hline Corruption & 0.028166 & $(6.190753)^{* * *}$ & & 0.000174 \\
(COR) & $(4.875192)^{* * *}$ & 0.052618 & 0.026440 & $(6.198883)^{* * *}$ \\
\hline Physical Capital & 0.2777829 & $(1.190141)$ & $(4.589075)^{* * *}$ & \multicolumn{1}{c|}{-} \\
(K) & $(4.359438)^{* * *}$ & - & 0.279970 & $(4.250093)^{* * *}$ \\
\hline GDP Per Capita & $1.95 \mathrm{E}-05$ & 0.000193 & $1.22 \mathrm{E}-05$ & 0.041171 \\
(PC) & $(0.413484)$ & $(5.163261)^{* * *}$ & $(0.248927)$ & $(4.478408)^{* * *}$ \\
\hline
\end{tabular}

Source: Author Compiled

Notes: Value of $\mathrm{t}$-statistics are in parentheses; ${ }^{*}$ significant at $10 \%$; ${ }^{* *}$ significant at $5 \%$; ${ }^{* * *}$ significant at $1 \%$.

After establishing the order of integration for the series, we next apply the FM- OLS to obtain the long run estimates for the variables. Before interpreting the findings, it is important to note that high corruption index implies low corruption; meanwhile low corruption index indicates high corruption. We first estimate the equation (1) and Table 4 presents the results for this model. The specification in columns 3 and 4 includes our transmission channel variables but not the corruption index.

The FM-OLS regressions reported in Table 4 show the sensitivity of the estimated effect of corruption on the growth rate. The results of the columns 3 and 4 in Table 4 show that the effect of corruption on economic growth is sensitive to the inclusion of the transmission channels including physical capital and human capital. In column (5), COR coefficient indicates that corruption has a significant negative effect on the growth rate when the plausible transmission channels are not included in the regression. From column 5 of Table 4, we note that the regression coefficient on corruption is 0.000174 . This coefficient is smaller than that of in columns 3 and 4 where the transmission channels were included 
separately. However, when both channels were included as in column 2, regression coefficient on corruption is 0.028166 . Out of four in three cases, the regression coefficient on corruption is statistically significant at the 1 percent level. The results indicate that physical capital has positive and significant impact on economic growth. This is consistent with economic theory, which specifies that capital stock is a vital factor for economic growth. Turning to the effect of population growth on economic growth, we observe that increases in population have enhanced economic performance, as the regression coefficient on POP is positive and statistically significant. The results confirm that in addition to direct effect, there is an influence from corruption to economic growth through physical capital and human capital. The results in Table 4 reveal that low corruption is stimulated economic growth in South Asian Countries.

Table 5. Fully Modified OLS Results - Long-Run (Dependent Variables- Physical and Human Capital)

\begin{tabular}{|l|c|c|}
\hline \multirow{2}{*}{ Independent Variables } & \multicolumn{2}{|c|}{ Dependent Variable } \\
\cline { 2 - 3 } & Physical Capital & Human Capital \\
\cline { 2 - 3 } & & \\
\hline \multirow{2}{*}{ Economic Growth (EG) } & 7.043694 & 0.043244 \\
\hline \multirow{3}{*}{ Human Capital (POP) } & $(2.230744)^{* *}$ & $(0.148304)$ \\
\hline \multirow{3}{*}{ Corruption (COR) } & -3.658493 & - \\
\hline \multirow{2}{*}{ Physical Capital (K) } & $(-3.187512)^{* * *}$ & -0.023815 \\
\hline
\end{tabular}

Source : Author Compiled

Notes: Value of $\mathrm{t}$-statistics are in parentheses; ${ }^{*}$ significant at $10 \%$; ${ }^{* *}$ significant at $5 \%$; ${ }^{* * *}$ significant at $1 \%$.

Next we investigated the indirect effect of physical and human capital on economic growth. We report results of two regression models of the transmission variables on corruption in Table 5. As can be seen in Table 5, corruption is found to be related to these variables in both positive ways, and this relationship is not statistically significant. From the result in column 2, we infer that a 1 percent increase in corruption increases physical investment by about 0.246 percent. This indicates that low corruption is associated with low investment for South Asian countries. Additionally, the results reveal that both economic and population growth have significant effect on investment. These results indicate both economic and population growth rates are important determinants of investment in South Asian countries. 
Column 3 of Table 5 presents the indirect effect of corruption on economic growth through human capital. The results reveal that corruption has positive (higher corruption level) influence on population growth, as the regression coefficient on COR is negative. This finding confirms the notion that corruption misuses talents of humans. It is clear that that in the presence of corruption, rent seeking tends to be more lucrative than productive work. Ehrlich and Lui (1999) showed that corruption encourages officials to engage in rent seeking and in the process accumulate political capital, which was socially unproductive. Economic growth has positive impact on population growth. From this result, there is an interesting point to note, which is human capital is positively correlated with growth suggests that corruption hence has shown growth-enhancing effect. Finally, results show that physical investment has negative significant influence on population growth at the 1 percent level of significance. This result implies that as investment decreases, population growth rises.

\section{Conclusion}

This paper has employed the FM-OLS procedure to examine the long-run relationship between economic growth and corruption for panel of four South Asian countries. Specifically, the study used the Levin, Lin \& Chu panel unit root procedure to determine the time series properties for economic growth, corruption, physical investment and human capital. As the panel unit root test results revealed, the data series was integrated of order (1), the study applied the FM-OLS procedure by using a panel data of four South Asian countries spanning over 2002-2016. The results suggested that corruption has both direct and indirect influence on economic growth in four countries. The results revealed few significant implications for these countries. First, the findings claim that a one-unit increase in corruption retards economic growth by roughly 0.0282 percent for the period under consideration. This finding was consistent with the findings of Gyimah-Brempong (2002). Second, the econometric results reveal the positive effect of physical and human capital on economic growth. Third, results claim that the effect of corruption on economic growth is sensitive to the inclusion of the transmission channels including physical capital and human capital. A study done by Mauro, (1995) reported that corruption was strongly negatively related with the private investment and, hence, it lowers the rate of economic growth.

Fourth, results indicate that the indirect effect of physical and human capital on economic growth. As can be seen from the findings, corruption is found to be related to these variables in both positive ways, and this relationship is not statistically significant. This reveals that low corruption is associated with low investment and low level of human capital for South Asian countries. Additionally, the results reveal that economic growth has significant positive effect on investment. Finally, results reveal that 
physical investment has negative significant influence on population growth at the 1 percent level of significance. This result implies that as investment decreases, population growth rises.

According to the findings, it is evident that actions should be taking to curb corruption at every level among the sample countries. Laws to decrease corruption should be vigorously pursued and imposed. Institutions should be established to enforce corruption laws and proper implementation of the existing laws is vital for reduce corruption among these countries. In doing so political commitment and support is essential. Fostering fundamental ethical and moral values among the society is also important. Encouraging accountability and transparency in public sector, active engage of the public and civil society is vital in order to curtail corruption in public sector of South Asian countries. Thus, it is more important than ever for governments to be doing the right thing, to retain public trust and gain a competitive advantage in an ever more accessible and transparent world.

\section{References}

Aidt, T., J. Dutta, and V. Sena 2008. Governance Regimes, Corruption and Growth: Theory and Evidence, Journal of Comparative Economics, 36, pp,195-220.

Acemoglu, D. and Verdier, T. (1998), "Property Rights, Corruption and the Allocation of Talent: A General Equilibrium Approach," Economic Journal, 108, 450: 1381-1403

Bardhan, P. K. (1997), Corruption and development: A review of issues, .Journal of Economic Literature, 35(3), 1320-1346.

Blackburn K. and Downing G. ( 2015), "Deconcentration, Corruption and Economic Growth," Centre for Growth and Business Cycle Research Discussion Paper Series 209, Economics, The University of Manchester

Gyimah-Brempong, K. (2002), Corruption, Economic Growth and Income Inequality in Africa, Economics and Governance, 3, 183-209

Ehrlich, I. and Lui. F.T. (1999), Bureaucratic Corruption and Endogenous Economic Growth, Journal of Political Economy, 107(6), S270-S293

Ehrlich, Isaac (1996), "Crime, Punishment, and the Market for Offenses," Journal of Economics Perspectives, 10: (43-67.

Huntington, S. P. (1968), Political Order in Changing Societies, New Heaven: Yale University Press

Johnston, Michael, (1997), "Public Officials, Private Interests, and Sustainable Democracy: When Politics and Corruption Meet," at: https://www.researchgate.net/publication/2540219

Leff, N.H. (1964), "Economic Development through Bureaucratic Corruption," American Behavioral Scientist, 8(3):8-14.

Meon, P-G and Sekkat, K (2005), Does Corruption Grease or Sand the Wheels of Growth? in: Public Choice, 122 (1/2): 69-97.

Mauro, P. (1995), "Corruption and Growth." Quarterly Journal of Economics 110: 618-712 
Mauro, P. (1998), "Corruption and the Composition of Government Expenditures." Journal of Public Economic, 69: 263-279.

Monte, Alfredo Del and Erasmo Papagni. (2001), "Public Expenditure, Corruption, and Economic Growth: The Case of Italy," European Journal of Political Economy, 17, 1, 1-16

Mo, Pak Hung. (2001), “Corruption and Economic Growth" Journal of Comparative Economics, 29, 66-79

Kholdy, S. and Sohrabian, A. (2008), Foreign Direct Investment, Financial Markets, and Political Corruption, Journal of Economic Studies, 35(6), 486-500

Leff, N.H. (1964), "Economic Development through Bureaucratic Corruption." American Behavioral Scientist, 8(3):8-14.

Lui F.T. (1996), “Three Aspects of Corruption," Contemporary Economic Policy, 14(3) 26-29.

Ratbek D, (2014), "Corruption and growth: The role of governance, public spending, and economic development," Economic Modelling, Elsevier, 37(C), 202-215.

Pellegrini, L. and Gerlagh, R. (2004), Corruption's Effect on Growth and Its Transmission Channels, Kyklos, 57(3), 429-456

Phillips, P.C.B. and Hansen, B.E. (1990), "Statistical Inference in Instrumental Variables Regression with me (1) Processes", Review of Economic Studies, 57, 99-125.

Swaleheen. M., and Stansel. D. (2007), Economic Freedom, Corruption and Growth, Cato Journal, 27(3), 343-358

Tanzi, V. (1998), Corruption around the world: Causes, consequences, scope, and cures. Staff PapersInternational Monetary Fund, 559-594.

Transparency International (2014), South Asia's corruption watchdogs need sharper teeth, Issued by Transparency International Secretariat 